\title{
The Chairman's Annual Report for the Year 1969-1970
}

The current session has been a successful one for the AngloByelorussian Society. Over the past year, nine new members have joined the Society: Very Revd. Archimandrite Leo Horoško, Mr James Dingley, Mrs Pauline Dingley, Mr Arnold McMillin, Mrs Caroline McMillin, Mr Victor Sidorievič, Dr Richard French, Mr Derek Webster, Revd. Robert Tamushanski and Mme Helen Michaluk, bringing the total number of the membership up to thirty. The Council expresses the hope that our membership will continue to expand, and that existing members will encourage friends who are interested in Byelorussian culture and history, to support the Society.

In the course of the past year two numbers of the Journal of Byelorussian Studies have been published (Vol. I, Nos. 3 \& 4 for the years 1967 and 1968) and during the latter half of the session a further number (Vol. II, No. 1 for the year 1969) has gone to press, and will no doubt be appearing some time in the autumn. Work is now progressing on the following number (Vol. II, No. 2 for the year 1970), and we hope this will be in the hands of the printers before the end of the year. The Journal has a circulation of over 500 copies reaching over 120 Universities, 55 Libraries and 46 Associations, Public bodies and Learned societies in all parts of the world. Income from the sales of the Journal during the current year amounted to $£ 230.15$.lid., which represents an increase of more than $£ 100$ over the previous year. It must be said that the former figure includes income from the sale of back-numbers of the Journal for which there is a continuing demand. Exchange arrangements exist inter alia with the Czech and Polish Academies of Sciences, with the Białystok Museum, the Byelorussian State Library, the University of Uppsala and the Biblioteca Nazionale in Rome. In addition the Society has distributed a number of fac-simile copies of a rare work by Romuald Ziemkievič on Jan Barščeǔski, first published in Vilna in 1911.

Six ordinary meetings of the Society were held at the Society of Antiquaries, Burlington House, Piccadilly, London W.1. at which members of the society, their guests and visitors attended the Fourth Course of Lectures organised annually by the Council. Attendances presented an improvement on the previous year, with numbers fluctuating between 33 and 20, and more than 30 attending on three occasions.

The Council, of the Society held meetings on 23 July 1969, on 6 November 1969 and on 30 April 1970 to dispatch the ordinary administrative business of the Society and its activities. The Editorial Board of the Journal of Byelorussian Studies has also met on a number of occasions during the past session to discuss problems 
arising out of present and future publications. The Distributor of the Journal has also submitted regular progress reports to the Council on his work. To him, and to those concerned with the publication of the Journal, I should like, on your behalf, to express our feelings of appreciation and gratitude.

On 17 January 1970 the Chairman and Hon. Secretary of the Society attended the opening of the new Byelorussian House in Bradford by the Lord Mayor, and your Chairman was called upon to give a brief reply to a toast proposed by the Chairman of the Association of Byelorussians in Great Britain, on behalf of the English guests. The following day the Hon. Secretary was the guest of honour at a reception organised by the Manchester Branch of the Association, at the Byelorussian House in Cheetham, Manchester.

As a result of the increased activities of the Society, particularly in the field of publications, and the organisation of the Lecture Course, the finances of the Society have had to meet heavy outgoings and commitments, and a net surplus of $£ 70$ for the year 1969 has been converted into a net deficiency for the year 1970 of $£ 86.0 .9 \mathrm{~d}$. We therefore appeal to our Members to assist in the raising of funds, in particular by paying their subscription to the Society regularly each year. Notwithstanding these heavy expenses, it is anticipated that finances in the coming year will permit the continued publication of the Journal.

The coming year will mark the fifth anniversary of the Society's Annual Course of Lectures. It is proposed to continue as we have done in the past, and I understand that the programme for the present year is being prepared by the Hon. Secretary. The premises of the Society of Antiquaries are well-suited to the purposes of our Society, and we may well return there this year, if the hall is available.

It is my hope that during the present session the Society will be able to press for greater Byelorussian representation in AngloSoviet cultural exchanges.

In concluding I should like to express my personal satisfaction over the achievements of the Society during the past five years, and to thank all our members, as well as the officers of the Council for their continued loyal support.

23 July 1970

AUBERON HERBERT

Chairman 